\title{
Factors of Share Price Volatility: Empirical Evidence from Private Commercial Banks in Bangladesh
}

\author{
Mohammad Zahed Hossain \\ Assistant Professor, Department of Business Administration, Leading University, Sylhet, Bangladesh \\ *E-mail of the Corresponding author: zahedbtc@gmail.com
}

\begin{abstract}
The objective of this study is to investigate the fundamental factors of share price volatility in Bangladesh specially the private commercial banks listed in the Dhaka Stock Exchange (DSE) Ltd. The price of shares in DSE is so volatile that it swings more frequently that's why investors become puzzled while making an investment decision. Thus, this study tries to investigate the association of share price with some fundamental factors like earnings per share, dividends per share, assets growth, bank size and two new variables namely capital to risk-weighted assets ratio and non-performing loan to total loans. Share prices of 18 commercial banks listed in DSE from 2014 to 2018 totaling 90 observations have been considered for analysis. This study applied panel data set in regression model using Fixed-Effects with Driscoll and Kraay's Standard Errors to test the hypothesis by STATA 13 software. The empirical result of the study presents that earnings per share, dividends per share, bank size and non-performing loan to total loans significantly affect the market price of shares. This study will extend the literature on factors of share prices in an emerging economy like Bangladesh. Furthermore, this study could be extended further by considering all listed firms of DSE which will give us more insight into share price volatility in Bangladesh.
\end{abstract}

Keywords: Share price volatility, Commercial banks, Investment decision, DSE, Bangladesh

DOI: $10.7176 /$ RJFA/11-4-12

Publication date: February $29^{\text {th }} 2020$

\section{Introduction}

Financial system is the mechanism of an economy that encompasses all the value-adding activities of a country. This system consists of different types of organs like financial markets namely capital market, money market, and financial institutions which include banks, insurance companies, leasing companies, microcredit institutions, etc. Capital market is the system that opens the avenue for the listed companies to accumulate long term funds as capital which may be equity or debt; or combination of both. Gompers, Ishii, and Metrick (2003) found that the book value of the firm, dividends per share, earnings per share, and price-earnings ratio influence the price of equity in the capital market.

Kurihara (2006) found that stock markets are essential for economic growth as they ensure the flow of resources to the most productive investment opportunities. The investment decision of the investors of the stock market is greatly influenced by the market price of a share (Uddin, Rahman \& Hossain, 2013). Investors take into account how their total returns are divided between dividends and market price appreciation (Khan, 2009). The yields from such investments vary depending on the performance of the individual stock in a market and the fluctuations of the stock price (Bhattarai, 2014). Srinivasan (2012) noticed that understanding the impact of various fundamental variables on stock price is very much helpful to investors as it will help them in making profitable investment decisions. Money supply influences the equity stock prices of the Malaysian capital market (Ibrahim, 2003).

Equity is of two types common stock and preferred stock, common stock interchangeably considers as share. Share is one of the most lucrative investment avenues for investors which consider as an outcome for a source of funds for the firms. Invest in equity share may produce two types of return one is dividends as a regular return and another is capital gain which is one-time return during the investment period. Since the dividends and capital gain are not fixed as a result total return is uncertain. Change in Stock price affects the return from equity share that is why share price volatility is a major concern of investors. Compared to the transition phase money market, long term economic growth is influenced by the stock market in Bangladesh (Hasan 2018).

There is no doubt that banks convert deposits into productive investments as a method to facilitate economic growth in any country (Levine et al., 2000). A reliable and efficient banking system has to achieve three goals: to give a considerable profit, to offer a high-quality service to customers, and to have sufficient funds to lend to borrowers. The growth of the economy of any country largely depends on its banking sector. Hence, the importance of bank profitability in the economy can be determined at the micro and macro levels. At the micro-level, profit is 
a determinant and required for any competitive banking institution. Every bank tries to earn and achieve good profits to be in the business especially at the time of growing competition in the financial markets. At the macro level, a profitable banking sector should be able to absorb external negative shocks and to achieve the stability of the financial system. It is notable that, the banking sector of developing countries is less stable than developed countries (Beck \& Rahman, 2006; Sufian \& Habibullah, 2009; Uddin \& Suzuki , 2011).

Although little research has been done to explain the relationship among share price volatility and some other variables and found associations with the fundamental variables but the market i.e Dhaka Stock Exchange is so volatile that it swings more frequently that's why investors become puzzled while making an investment decision. This study tries to reinvestigate the association of share price with some fundamental factors like earnings per share, dividends per share, assets growth, bank size and two new variables capital to risk-weighted assets ratio, non-performing loan to total loans.

\section{Literature Review}

Long since researchers from various countries have been trying to identify the factors behind the stock price volatility by conducting a number of studies throughout the world in different stock markets. Collins (1957) one of the pioneering researchers conducted study on US banks found dividend, net profit, operating earnings per share, and book value per as the factors influencing share prices. Guo (2002) considers share price volatility as a systemic risk faced by common stock holders. In his study he found returns positively relate to past volatility, but negatively relate to current volatility.

Rehman, Abbas and Qureshi (2017) used panel data from the year 2014 to 2016 of ten banks listed in Pakistan stock exchange, they consider share price volatility as dependent variable and dividend policy as independent variable along with that dividend yield and dividend payout were used as proxy of dividend policy. After analyzing data they found that dividend yield \& growth has negative relationship with share price and dividend payout ratio $\&$ asset size shows insignificant relationship with share price in the banking industry of Pakistan. In Pakistan, Ghauri (2014) uses fixed effect regression model to find the factors of changes in share prices in banking industry considering dependent variable share price and independent variables size, dividend yield, return on asset, and asset growth where he observed except size other variables have insignificant relationship with the share price.

Akbar and Afiezan (2018) measure the influence of fundamental factors and macro-economic factors on sharia stock price in Indonesia, data were collected through purposive sampling technique and t-test, f-test and determination coefficient methods were employed for analyzing the data. Their analysis shown that Earning per Share (EPS), Return on Assets (ROA), Debt to Equity Ratio (DER) and Exchange Rate significantly influence stock prices. On the other hand, the interest rate has no significant effect on stock prices. Syafri (2012) analyzed the factors that affect the profit of commercial banks in Indonesia found that loan to total assets, total equity to total assets, loan loss provision to total loan have positive effect on profitability, while inflation rate, the size of bank and cost-to-income ratio (BOPO) have negative effect on profitability. Economic growth and non-interest income to total assets are irrelevant to bank profitability.

Almumani (2014) tried to find fundamental factors that influence share prices for the listed banks in Amman Stock Exchange from the year 2005-2011 using empirical analysis of dependent variable: Dividend per Share, Earnings per Share, Book Value, Dividend Payout Ratio, Price/Earnings Ratio, Size and explanatory variable: Market price. He used ratio analysis, Correlation and a linear multiple regressions models to measure the individual as well as combined effects of independent variables on the dependent variables and the analysis showed positive correlation between dividends per share, earning per share, book value, price earnings ratio and size of the bank. In his study regression analysis shows significant relationship between book value and market price, positive relationship between price earnings ratio and market price, inverse relationship between size and market price whereas dividend per share \& dividend payout has insignificant relationship.

Sharif, Purohit and Pillai (2015) try to identify factors affecting share price of listed companies in the Bahrain stock exchange. Fixed effects, random effects and pooled OLS regression with robust standard errors methods were used to analyze a panel data set of 41 listed companies for 5 years from the year 2006 to 2010 . Their analysis indicate that share price in the Bahrain market is highly influenced by return on equity, book value per share, dividend per share, dividend yield, price earnings, and firm size. In Turkey, Anbar and Alper (2011) examined bank-specific and macroeconomic factors of the bank's profitability for eight years for the period $2002-2010$. 
Balanced panel data used for analyzed dependent variables return on equity \& return on assets, independent variables are two categories Bank-Specific Independent Variables: Asset Size, Capital Adequacy, Asset Quality, Liquidity, Deposit, Income-Expenditure Structure, and Macroeconomic Independent Variables: Economic Activity, Inflation, Interest Rate. After analysis they have found that asset size and non-interest income have significant positive effect on bank profitability. On the other hand, size of credit portfolio and loans under followup have significant negative impact on bank profitability. In case of macroeconomic variables, only the real interest rate positively affects banks profitability.

Dutta, Saha and Das (2018) tried to identify the significant factors affecting P/E ratio of manufacturing companies listed in Dhaka stock exchange by using descriptive statistics, correlation matrix and regression analysis in which they reveal that dividend yield and size have negative influence but leverage and net asset value per share have positive influence on P/E ratio. Islam (2018) examined the determinants of dividend policy on banking industry of Bangladesh by analyzing twenty years data from 1994 to 2013 of twenty two listed banks in Dhaka Stock Exchange (DSE). He used descriptive statistics and multiple regression analysis to check association between Dependent Variable: Dividend Payout Ratio (DPR) and Independent Variables: Lagged dividend payout ratio, Earnings per share, Cash flow, Sale growth, liquidity, Institutional ownership, Sponsor ownership, Individual ownership, Leverage, Risk, Age, Size, Relative tax, Return on assets, Investment Opportunity, Retained earnings to equity, and found significant determinants are retained earnings to equity, size, lagged dividend payout ratio (DPR). Among them risk tolerance, true accounting information, past and present stock performance, earning per share, GDP and other Macroeconomic issues of the country, political stability are noteworthy.

Sarbabidya and Saha (2018) focused on factors affecting investment decisions in Bangladesh Stock Market, in this study primary data were collected through structured self-administered questionnaire from 100 potential investors by convenience sampling method and 25 factors have been considered by analyzing secondary sources. They concluded that risk factors, stockholder's whimsical attitude, earning per share, political instability, uncontrollable macroeconomic factors, etc. detrimental to make investment decision. Uddin (2009) employed multiple regression analysis to find association between dependent variable market price and independent variables: Net Asset Value per Share, Dividend percentage, Earnings per Share on bank, leasing and insurance companies of Bangladesh listed on Dhaka stock exchange and found a significant linear relationship among market return and net asset value per share, dividend percentage, earning per share of bank leasing and insurance companies.

Rahman, Hamid \& Khan (2015) took initiative to determine the factors behind the profitability of 25 listed commercial Bangladeshi banks for the period of year 2006 to 2013 and unbalanced panel data is used in the study due to ensure degree of freedom as data for all the sample banks were not available. Their observed findings showed that regulatory capital, equity capital and loan intensity have positive and significant impact on profitability whereas cost efficiency and off-balance sheet activities have negative and significant impact on bank profitability. Return on assets significantly depends on size of the bank and net interest margin was affected by non-interest income, credit risk and growth in gross domestic product (GGDP). Haque, Jahiruddin \& Mishu (2019) apply correlation and multiple regression on 11 years' (from year 2004 to 2014) data of 35 manufacturing companies listed in Dhaka Stock Exchange (DSE) of Bangladesh to find association between share price volatility and dividend policy. After analyzing data the study found that among predictive variables, dividend yield and size of the firm have major impact on share price volatility.

Haque, Jahiruddin and Mishu (2019) studied the effect of dividend yield and dividend payout ratio on stock price instability by applying correlation and multiple regression analysis based on data from the year 2004 to 2014 of 35 manufacturing companies listed in Dhaka Stock Exchange (DSE) of Bangladesh. They also consider size, earning volatility, and debt as control variables. Their analysis suggests that dividend yield and size of the firm inversely affect the share volatility.

\section{Research Methodology}

This section provides a discussion of data collection, sampling procedure, models and econometric tools used by this study. 


\subsection{Data Collection and Sampling}

The data were collected from the most authentic sources, from the published annual reports of the respective banks. Only conventional private commercial banks listed in the Dhaka Stock Exchange (DSE), Bangladesh are considered. There are 24 conventional private commercial banks listed in DSE among them 18 were considered as sample, due to lack of data 6 were not included. Five-year time horizon, from the year 2014 to 2018 , was considered to construct the panel. This study excludes all Islamic banks listed in DSE due to differences in the modus operandi.

\subsection{Dependent Variable}

The dependent variable of this study is Market Value per Share (MP) in Bangladeshi currency i.e. taka per share. Each year's last working day share price, from the year 2014 to 2018, has been considered.

\subsection{Independent Variables}

Independent variables are considered in two ways, first most widely used fundamental variables were selected by intensive literature review for reinvestigation of the relationship and secondly two new variables are included that are highly weighted by the regulatory body according to Basell-II and Basell-III. Following variables are included in this study. EPS represents Earning per Share, Div. represents Dividends per Share, ROE represents Return on Equity, AG represents Assets Growth, LnBS represents Ln Bank Size (natural logarithm of total assets), CRAR represents the Capital to Risk-Weighted Assets Ratio, and NPL represents Non-performing Loan to Total Loans.

\subsection{Hypotheses}

$\mathrm{H}_{1}$ : There is a significant positive relationship between Market Value per Share (MP) and Earnings per Share (EPS),

$\mathrm{H}_{2}$ : There is a significant positive relationship between Market Value per Share (MP) and Dividends per Share (Div.),

$\mathrm{H}_{3}$ : There is a significant positive relationship between Market Value per Share (MP) and Return on Equity (ROE), $\mathrm{H}_{4}$ : There is a significant positive relationship between Market Value per Share (MP) and Assets Growth (AG), $\mathrm{H}_{5}$ : There is a significant positive relationship between Market Value per Share (MP) and Bank Size (BS),

$\mathrm{H}_{6}$ : There is a significant relationship between Market Value per Share (MP) and Capital to Risk-Weighted Assets Ratio (CRAR)

$\mathrm{H}_{7}$ : There is a significant relationship between Market Value per Share (MP) and Non-performing Loan to Total Loans (NPL).

Linear function model is used to test the hypothesis.

\subsection{Research Model}

The current study examines Market Value per Share as a function of Earnings per Share (EPS), Dividends per Share (Div.), Return on Equity(ROE), Assets Growth(AG), Bank Size (BS), Capital to Risk-Weighted Assets Ratio(CRAR) and Non-performing Loan to Total Loans(NPL).

Linear function model (linear variable and parameters):

$M P_{i t}=\beta_{0}+\beta_{1} E P S_{i t}+\beta_{2} \operatorname{Div}_{i t .}+\beta_{3} R O E_{i t .}+\beta_{4} A G_{i t .}+\beta_{5} L n B S_{i t .}+\beta_{6} C R A R_{i t .}+\beta_{7} N P L_{i t .}+\varepsilon_{i t .}$

$\boldsymbol{\varepsilon}=$ Error terms, $\boldsymbol{\beta}_{\mathbf{0}}=$ constant term Independent and $\boldsymbol{\beta}_{\mathbf{1}}$ to $\boldsymbol{\beta}_{7}=$ regression coefficient for respective variables 


\section{Analysis and Findings}

\subsection{Descriptive Analysis}

Table 1: Descriptive Statistics

\begin{tabular}{llllll}
\hline Variable & Obs & Mean & Std. Dev. & Min & Max \\
\hline MP & 90 & 29.05511 & 27.91899 & 8.6 & 153.1 \\
EPS & 90 & 3.304222 & 2.888639 & -0.28 & 21 \\
Div & 90 & 0.187472 & 0.155557 & 0.1 & 1.5 \\
ROE & 90 & 0.122442 & 0.039589 & -0.0115 & 0.2216 \\
AG & 90 & 0.133226 & 0.056042 & -0.007 & 0.2852 \\
CRAR & 90 & 0.125377 & 0.014136 & 0.0901 & 0.1704 \\
lnBS & 90 & 12.30474 & 0.313457 & 11.61714 & 12.92329 \\
NPLtoTL & 90 & 0.053192 & 0.015554 & 0.0208 & 0.0903 \\
\hline
\end{tabular}

The above table provides descriptive statistics i.e maximum, minimum, mean and standard deviation for dependent and independent variables used in this study for the period of five years from the year 2014 to 2018. From analysis, it is observed that market price ranges from 153.10 to 8.60 with a mean of 29.06 and a standard deviation of 27.92 . The value of mean and standard deviation for EPS 3.30\&2.89, Div. 0.19\&0.16, ROE 0.12\&0.04, AG 0.13\&0.06, LnBS 5.34\&0.14, CRAR $0.13 \& 0.01$ and NPL $0.05 \& 0.02$ respectively.

\subsection{Correlation Matrix and VIF}

Correlation matrix shows the relationship between two variables, this relationship can be categorized into three parts which are low (0.10-0.29), medium (0.30-0.49) and high (0.50-0.99) correlation (Pallant, 2011).

\section{Table 2: Correlation Matrix with MP}

\begin{tabular}{|c|c|c|c|c|c|c|c|c|}
\hline & MP & EPS & Div & ROE & $\mathrm{AG}$ & CRAR & $\ln B S$ & $\begin{array}{l}\text { NPLtoT } \\
\mathrm{L}\end{array}$ \\
\hline MP & 1 & & & & & & & \\
\hline EPS & $0.8595 * * *$ & 1 & & & & & & \\
\hline Div & $0.6471 * * *$ & $\begin{array}{l}0.8380 * * \\
*\end{array}$ & 1 & & & & & \\
\hline ROE & $0.3935 * * *$ & $\begin{array}{l}0.5054 * * \\
*\end{array}$ & $\begin{array}{l}0.4068 * * \\
*\end{array}$ & 1 & & & & \\
\hline $\mathrm{AG}$ & -0.0001 & 0.0024 & -0.0367 & $0.2253 * *$ & 1 & & & \\
\hline CRAR & $0.3080 * * *$ & $\begin{array}{l}0.3120 * * \\
*\end{array}$ & $\begin{array}{l}0.2759 * * \\
*\end{array}$ & 0.1144 & -0.1638 & 1 & & \\
\hline $\ln B S$ & $0.3297 * * *$ & $0.2029 *$ & 0.1355 & -0.0975 & -0.1289 & $\begin{array}{l}0.3388 * * \\
*\end{array}$ & 1 & \\
\hline $\begin{array}{l}\text { NPLtoT } \\
\mathrm{L}\end{array}$ & $-0.248 * *$ & $-0.2492 * *$ & $-0.2343 * *$ & $-0.4683 * * *$ & -0.1631 & -0.1559 & -0.018 & 1 \\
\hline
\end{tabular}

Significant at $* 1 \%, * * 5 \%, * * * 10 \%$ level of significance

This study presents correlation matrix in table 2 which represent the correlation between the independent variables. From table 2, this study documented the highest correlation between MP and EPS which is $85.95 \%$, significant at $1 \%$ level, whereas the lowest correlation exists between MP and AG i.e. $0.01 \%$ and insignificant. Most of the variables in this study have a medium level of correlation. It is mentioned that there is no correlation between variables which is higher than $90 \%$ as a sign of no multi-collinearity. 
Table 3: VIF and Tolerance value

\begin{tabular}{|l|l|l|}
\hline Name of Variable & VIF & Tolerance value \\
\hline EPS & 4.05 & 0.246908 \\
\hline Div & 3.42 & 0.292093 \\
\hline ROE & 1.79 & 0.559726 \\
\hline NPLtoTL & 1.32 & 0.757735 \\
\hline CRAR & 1.26 & 0.793341 \\
\hline InBS & 1.22 & 0.818714 \\
\hline AG & 1.12 & 0.894163 \\
\hline Mean VIF & 2.03 & \\
\hline
\end{tabular}

In addition to the correlation matrix, this study also considers VIF and tolerance value to examine the issue of multicollinearity, present in table 3 (Hamilton, 2012). VIF value of all study variables is below 5 where tolerance value is more than 0.10 . Literature suggests that VIF value below should be 10 and in correspondence to the VIF value, tolerance value should be 0.10 (Allison, 2012; Burns \& Bush, 2005; Hair, Black, Babin, Anderson, \& Tatham, 2006). It means that there is no multicollinearity issue in the study model.

\subsection{Test for and Heteroskedasticity and Cross Sectional Dependence}

This study also applied Breusch-Pagan and Pesaran tests to clarify the issue of heteroskedasticity and Cross Sectional Dependence in the data set. The results of both tests are presented in table 4, where the study documented that data used for the study has heteroskedasticity and Cross Sectional Dependence issues, as both test results are significant at $1 \%$ level. Therefore, this study corrected the two issues by employing Driscoll and Kraay's standard errors based on Hoechle (2007) which is robust to heteroskedasticity and Cross Sectional Dependence. The adjusted Driscoll and Kraay's standard errors by Hoechle (2007) is a nonparametric covariance matrix estimates fixed-effect model and valid for balanced and unbalanced panel data.

Table 4: Results of Heteroscedasticity and Cross Sectional Dependence Tests

\begin{tabular}{|c|l|}
\hline $\begin{array}{l}\text { Breusch-Pagan / Cook-Weisberg test for } \\
\text { heteroscedasticity }\end{array}$ & Cross Sectional Dependence Test \\
\hline Ho: Constant variance & $\begin{array}{l}\text { Pesaran's test of cross sectional independence }= \\
\text { Variables: fitted values of MP }\end{array}$ \\
chi2(1) $=37.17$ & $\begin{array}{l}\text { Average absolute value of the off-diagonal elements }= \\
0.503\end{array}$ \\
Prob $>$ chi2 $=0.0000$ & \\
\hline
\end{tabular}

\subsection{Regression Analysis}

The analysis of this study shows that earnings per share, dividend per share, bank size and non-performing loan to total loan significantly affect the market price of share but assets growth, return on equity, capital to risk-weighted assets ratio do not have any significant effect on market price of share of commercial banks listed in DSE. 
Table: 5: Result of Regression Model Using Fixed-Effects with Driscoll and Kraay's Standard Errors

\begin{tabular}{ll}
\hline VARIABLES & MP \\
\hline EPS & $10.05^{* * *}$ \\
Div & $(1.284)$ \\
& $-42.38^{*}$ \\
ROE & $(23.24)$ \\
& -38.10 \\
AG & $(27.25)$ \\
& 4.243 \\
CRAR & $(15.65)$ \\
& -7.071 \\
lnBS & $(65.77)$ \\
& $13.06^{* *}$ \\
NPLtoTL & $(5.792)$ \\
& $-118.6^{* * *}$ \\
Constant & $(34.32)$ \\
& $-145.6^{* *}$ \\
Observations & $(62.23)$ \\
Number of groups & 90 \\
R-squared & 18 \\
\hline
\end{tabular}

Standard errors in parentheses

$* * * \mathrm{p}<0.01, * * \mathrm{p}<0.05, * \mathrm{p}<0.1$

\section{Conclusion}

The analysis of this study shows that earnings per share, dividends per share, bank size and non-performing loan to total loan significantly affect the market price of share on the other hand assets growth, return on equity, capital to risk-weighted assets ratio do not have any significant effect on market price of share of commercial banks listed in DSE. The findings of the study can't be generalized to the entire banking industry of Bangladesh. Additionally, this study can be extended by considering public and foreign banks listed in DSE also the study can be applied to several different industries like Financial Institutions, Insurance, IT sector, and Pharmaceuticals \& Chemicals, etc. listed in DSE which will give more insight of share price volatility in Bangladesh.

\section{References}

Abbas, S. G., \& Qureshi, M. I. (2017). The impact of dividend policy on share price volatility in the context of banking sector of Pakistan. Journal of Managerial Sciences, 11(03), 199-214

Akbar, T., \& Afiezan, A. (2018). Determination of sharia stock price through analysis of fundamental factors and macro economic factors. Account and Financial Management Journal, 3(10), 1739-1745.

Almaqtari, F. A., Al-Homaidi, E. A., Tabash, M. I., \& Farhan, N. H. (2019). The determinants of profitability of Indian commercial banks: A panel data approach. International Journal of Finance \& Economics, 24(1), 168-185.

Almumani, M. A. (2014). Determinants of equity share prices of the listed banks in Amman stock exchange Quantitative approach. International Journal of Business and Social Science, 5(1), 91-104.

Anbar, A., \& Alper, D. (2011). Bank specific and macroeconomic determinants of commercial bank profitability: Empirical evidence from Turkey. Business and Economics Research Journal, 2(2), 139-152.

Beck, T., \& Levine, R. (2004). Stock markets, banks, and growth: Panel evidence. Journal of Banking \& Finance, 28(3), 423-442.

Beck, T., \& Rahman, M. H. (2006). Creating a More Efficient Financial System: Challenges for Bangladesh. World Bank Policy Research Working Paper 3938.

Bhattarai, Y. R. (2014). Determinants of share price of Nepalese commercial banks. Economic Journal of Development, 17(1), 1-12.

Collins, J. (1957). How to study the behavior of bank stocks. Financial Analysts Journal, 13(2), 109-113.

Dutta, K. D., Saha, M., \& Das, D. C. (2018). Determinants of PE ratio an empirical study on listed manufacturing companies in DSE. International Journal of Scientific and Research Publications, 8 (4), 167-174.

Gompers, P., Ishii, J., \& Metrick, A. (2003). Corporate governance and equity prices. The Quarterly Journal of Economics, 118(1), 107-156.

Haque, R., Jahiruddin, A. T. M., \& Mishu, F. (2019). Dividend policy and share price volatility: A study on Dhaka 
Stock Exchange. Australian Academy of Accounting and Finance Review, 4(3), 89-99.

Hasan, M. A. (2018). Does stock market development promote economic growth? A bounds testing analysis for Bangladesh. Jurnal Perspektif Pembiayaan Dan Pembangunan Daerah, 6(1), 69-78.

Hui Guo, 2002. "Stock market returns, volatility, and future output," Review, Federal Reserve Bank of St. Louis, issue sep, pages 75-86.

Ibrahim, M. (2003). Macroeconomic forces and capital market integration A VAR analysis for Malaysia. Journal of the Asia Pacific Economy, 8(1), 19-40.

Islam, M. S. (2018). Determinants of divided policy: Study on banking sector of bangladesh. Parikalpana: KIIT Journal of Management, 14(2), 1-18.

Islam, M. S. (2018). Influencing factors of dividend policy in bangladesh survey evidence from listed banks in dse. Siddhant-A Journal of Decision Making, 18(3), 210-223.

Khan, S.H. (2009), Determinants of Share Price Movements in Bangladesh: Dividends and Retained Earnings. Available from: http://www.diva-portal.org/smash/get/diva2:832110/FULLTEXT01.pdf. [Last accessed 2015 Sep 06].

Kurihara, Y. (2006). The relationship between exchange rate and stock prices during the quantitative easing policy in Japan. International Journal of Business, 11(4), 375.

Levine, R., Loayza, N., \& Beck, T. (2000). Financial intermediation and growth: Causality and causes. Journal of Monetary Economics, 46(1), 31-77.

Mohammad Khan Ghauri, S. (2014). Determinants of changes in share prices in banking sector of Pakistan. Journal of Economic and Administrative Sciences, 30(2), 121-130.

Rahman, M. M., Hamid, M. K., \& Khan, M. A. M. (2015). Determinants of bank profitability: Empirical evidence from Bangladesh. International Journal of Business and Management, 10(8), 135-150.

Sarbabidya, S., \& Saha, T. (2018). Factors affecting investment decisions: A study on Bangladesh Stock Market. Journal of Accounting, 8(2), 1-19.

Sharif, T., Purohit, H., \& Pillai, R. (2015). Analysis of factors affecting share prices: The case of Bahrain stock exchange. International Journal of Economics and Finance, 7(3), 207-216.

Srinivasan, P. (2012). Determinants of equity share prices in India: A panel data approach. The Romanian Economic Journal, 46(6), 205-228.

Sufian, F., \& Habibullah, M. S. (2009). Determinants of bank profitability in a developing economy: Empirical evidence from Bangladesh. Journal of Business Economics and Management, 10(3), 207-217.

Syafri, M. (2012, September). Factors affecting bank profitability in Indonesia. In The 2012 International Conference on Business and Management (Vol. 237, No. 9, pp. 7-8).

Tabassum, C., Dovash, R. H., \& Sharul, I. (2019). Determinants of Stock Price of Financial Sector-A Study on Banks and Non-Bank Financial Institutions in Bangladesh, International Journal of Business and Technopreneurship, Volume 9, No 1, Feb 2019 [49-56]

Uddin, M. B. (2009). Determinants of market price of stock: A study on bank leasing and insurance companies of Bangladesh. Journal of modern Accounting and Auditing, 5(7), 1-6.

Uddin, M. R., Rahman, Z. \& Hossain, R. (2013). Determinants of stock prices in financial sector companies in Bangladesh-A study on Dhaka Stock Exchange (DSE). Interdisciplinary Journal of Contemporary Research in Business, 5(3), 471-480.

Uddin, S. M. S., \& Suzuki, Y. (2011). Financial Reform, Ownership and Performance in Banking Industry: The Case of Bangladesh. International Journal of Business and Management, 6(7), 28-39. 